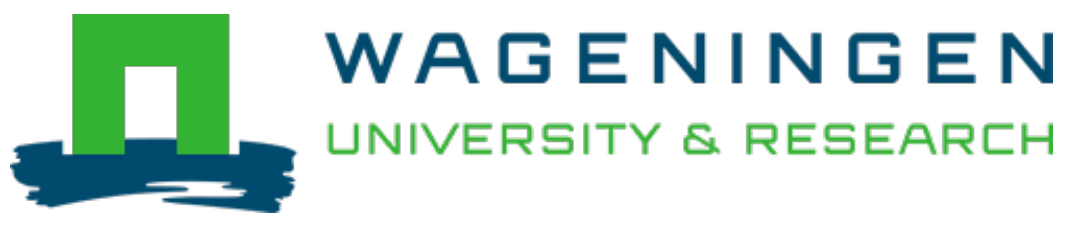

\title{
A modified extraction protocol enables detection and quantification of celiac disease-related gluten proteins from wheat
}

Journal of Chromatography. B, Analytical technologies in the biomedical and life sciences

Broeck, H.C.; America, A.H.P.; Smulders, M.J.M.; Bosch, H.J.; Hamer, R.J. et al

https://doi.org/10.1016/j.jchromb.2009.02.035

This article is made publicly available in the institutional repository of Wageningen University and Research, under the terms of article $25 \mathrm{fa}$ of the Dutch Copyright Act, also known as the Amendment Taverne. This has been done with explicit consent by the author.

Article 25 fa states that the author of a short scientific work funded either wholly or partially by Dutch public funds is entitled to make that work publicly available for no consideration following a reasonable period of time after the work was first published, provided that clear reference is made to the source of the first publication of the work.

This publication is distributed under The Association of Universities in the Netherlands (VSNU) 'Article $25 \mathrm{fa}$ implementation' project. In this project research outputs of researchers employed by Dutch Universities that comply with the legal requirements of Article $25 \mathrm{fa}$ of the Dutch Copyright Act are distributed online and free of cost or other barriers in institutional repositories. Research outputs are distributed six months after their first online publication in the original published version and with proper attribution to the source of the original publication.

You are permitted to download and use the publication for personal purposes. All rights remain with the author(s) and / or copyright owner(s) of this work. Any use of the publication or parts of it other than authorised under article $25 \mathrm{fa}$ of the Dutch Copyright act is prohibited. Wageningen University \& Research and the author(s) of this publication shall not be held responsible or liable for any damages resulting from your (re)use of this publication.

For questions regarding the public availability of this article please contact openscience.library@,wur.nl 


\title{
A modified extraction protocol enables detection and quantification of celiac disease-related gluten proteins from wheat
}

\author{
Hetty C. van den Broeck ${ }^{\mathrm{a}, *}$, Antoine H.P. America ${ }^{\mathrm{a}}$, Marinus J.M. Smulders ${ }^{\mathrm{a}, \mathrm{b}}$, Dirk Bosch ${ }^{\mathrm{a}}$, \\ Rob J. Hamer ${ }^{c}$, Ludovicus J.W.J. Gilissen ${ }^{\mathrm{a}, \mathrm{b}}$, Ingrid M. van der Meer ${ }^{\mathrm{a}, \mathrm{b}}$ \\ a Plant Research International, Wageningen UR, PO Box 16, 6700 AA Wageningen, The Netherlands \\ ${ }^{\mathrm{b}}$ Allergy Consortium Wageningen, PO Box 16, 6700 AA Wageningen, The Netherlands \\ c Laboratory of Food Chemistry, Wageningen University, PO Box 8129, 6700 EV Wageningen, The Netherlands
}

\section{A R T I C L E I N F O}

\section{Article history:}

Received 19 December 2008

Accepted 19 February 2009

Available online 25 February 2009

\section{Keywords:}

Celiac disease

Gluten protein extraction

Gliadins

Glutenins

Immunoblotting

Monoclonal antibodies

Wheat

R5

\begin{abstract}
A B S T R A C T
The detection, analysis, and quantification of individual celiac disease (CD) immune responsive gluten proteins in wheat and related cereals (barley, rye) require an adequate and reliable extraction protocol. Because different types of gluten proteins behave differently in terms of solubility, currently different extraction protocols exist. The performance of various documented gluten extraction protocols is evaluated for specificity and completeness by gel electrophoresis (SDS-PAGE), immunoblotting and RIDASCREEN ${ }^{\circledR}$ Gliadin competitive ELISA. Based on these results, an optimized, two-step extraction protocol has been developed.
\end{abstract}

(c) 2009 Elsevier B.V. All rights reserved.

\section{Introduction}

Gluten proteins (prolamins) from wheat, rye, and barley are characterized by high proline and glutamine content. Due to the occurrence of especially these amino acids in specific motifs, these proteins can provoke celiac disease $(\mathrm{CD})$ in susceptible individuals possessing T-cells with HLA-DQ2 or HLA-DQ8 receptors. HLA-DQ2 is present in $90-95 \%$ of CD patients [1] and HLA-DQ8 is found in the remaining 5-10\% [2-4]. Exposure to gluten proteins leads to damage of the small intestine [5,6], which causes a range of symptoms including altered bowel habits, malnutrition and weight loss. About $0.5-1 \%$ of the Western population suffers from CD, which makes it one of the largest food sensitivities worldwide. The only way to avoid symptoms is to maintain a life-long strict glutenfree diet. Currently, there is an increasing application of wheat gluten in various processed food products, ranging from meats to sweets, with several of these products unexpectedly containing gluten proteins. This increasing application in food products hinders CD-patients to maintain their gluten-free diet and makes

\footnotetext{
* Corresponding author. Tel.: +31 317 480974; fax: +31 317418094

E-mail address: hetty.busink@wur.nl (H.C. van den Broeck).
}

them dependent on reliable testing and labeling by food producers. Such testings require optimal gluten detection and quantification protocols.

In wheat, gluten proteins are comprised of monomeric gliadins and polymeric glutenins, which are present in approximately equal amounts. Together they form $80 \%$ of the total storage protein content in the wheat kernel. The remaining proteins are albumins (12\%) and globulins (8\%). These storage proteins have been classified based on their solubility in water, salt, and alcohol solutions [7]. Albumins are soluble in water and diluted (neutral) buffers, globulins are salt-soluble, gliadins are alcohol-soluble (40-70\%), and glutenins are soluble in alcohol under reducing conditions and in diluted acid or alkali. The gliadins form a large protein family in which $\alpha / \beta$-, $\gamma$-, and $\omega$-gliadins can be distinguished [8], whereas the glutenins are subdivided into low-molecular weight glutenin subunits (LMW-GS) and high-molecular weight glutenin subunits (HMW-GS) [9]. Gliadins and glutenins are in general extracted by alcohol solutions, containing a reducing agent for extracting glutenins [10-19]. In spite of the differences in solubility characteristics, co-extraction of glutenins in gliadin extracts and vice versa appears to be inevitable.

Gluten extracts can be tested for the presence of T-cell stimulatory proteins by immunoassays and immunoblotting using mAbs against $\mathrm{T}$-cell stimulatory gluten peptides. Existing immunoas- 
says differ in the antibodies used and in the test format [20-27]. A drawback of these immunoassays is their extraction protocol. It uses only $60 \%$ aqueous ethanol, because the presence of reducing agents would interfere with the immunoassay $[22,28]$. However, the use of reducing agents (2-mercaptoethanol, DTT) has been shown to improve the extraction efficiency of glutenins. Further studies have shown that the use of reducing agents (2mercaptoethanol and guanidiniumchloride) in a 1:100 dilution does not affect immunoreactivity and is used in the R5 capture ELISA [24,26,29]. This ELISA is approved by the Codex Alimentarius Commission (2008) [30]. The monoclonal antibody in this assay, named R5, mainly recognizes QQPFP, QQQFP, LQPFP, and QLPFP sequences that occur in gliadins, secalins, and hordeins [24,31]. The R5 assay thus focuses on gliadins and not on T-cell stimulatory epitopes. However, also T-cell stimulatory motifs are known from glutenins [33,34], which will not be detected using the R5 antibody. It is not known to what extent the R5 assay yields different results from direct detection of T-cell stimulatory epitopes.

Here, we describe the development of a fast and efficient twostep extraction protocol for gluten proteins from wheat flour, based on a combination and optimization of documented extraction protocols for gliadins and glutenins. First, we analyzed the degree of (co-)extraction of individual extraction protocols by SDS-PAGE and gel staining, followed by comparative testing of the efficiency with our two-step protocol. Our two-step extraction protocol was compared to an existing $60 \%$ aqueous ethanol extraction protocol, first by immunoblotting using specific monoclonal antibodies against $\mathrm{T}$ cell stimulatory epitopes Glia- $\alpha 9[25,32]$ and LMW-GS [32,33], and second in the RIDASCREEN ${ }^{\circledR}$ Gliadin competitive ELISA based on the R5 monoclonal antibody. We used the RIDASCREEN ${ }^{\circledR}$ Gliadin competitive ELISA instead of the RIDASCREEN ${ }^{\circledR}$ Gliadin, because that is a sandwich ELISA that needs at least two epitopes for detection. Our two-step protocol enabled a highly complete extraction of gliadins and glutenins from wheat, compatible with a reliable detection assay to test for $\mathrm{CD}$-toxicity of foods using specific mAbs based on T-cell stimulatory peptides.

\section{Experimental}

\subsection{Flour}

Wheat grains of four hexaploid wheat varieties, Bovictus, Combi, Rektor, and Bussard, were obtained from Limagrain, Lelystad, The Netherlands, and were ground in an analytical mill (A 11 Basic, IKAWerke) and sieved through mesh $(0.5 \mathrm{~mm})$.

Different protocols for extraction of gluten proteins from wheat flour were tested as illustrated in Fig. 1 and are described below.

\subsection{Extraction of gluten proteins from wheat flour}

\subsubsection{Separate 'gliadin' and 'glutenin' extracts}

See Fig. 1A. According to Singh et al. [12] first, gliadins were extracted from $200 \mathrm{mg}$ wheat flour by addition of $1 \mathrm{ml}$ of $50 \%(\mathrm{v} / \mathrm{v})$ aqueous iso-propanol with continuous mixing (MS1 Minishaker, IKA Works, Inc.) at $1000 \mathrm{rpm}$ for $30 \mathrm{~min}$ at room temperature, followed by centrifugation at $2500 \times \mathrm{g}$ for $15 \mathrm{~min}$ at room temperature. The supernatant is referred to as ' 1 st gliadin extract'. The residue was extracted twice with $50 \%(\mathrm{v} / \mathrm{v})$ aqueous iso-propanol resulting in a '2nd and 3rd gliadin extract'. Second, the 'glutenin extract' was obtained by extraction of the residue with $1 \mathrm{ml}$ of $50 \%(\mathrm{v} / \mathrm{v}$ ) aqueous iso-propanol, $50 \mathrm{mM}$ Tris- $\mathrm{HCl}$ ( $\mathrm{pH} 7.5$ ) containing $1 \%(\mathrm{w} / \mathrm{v})$ DTT for $30 \mathrm{~min}$ at $60^{\circ} \mathrm{C}$ with mixing every 5 to $10 \mathrm{~min}$, followed by centrifugation at $10,000 \times g$ for $10 \mathrm{~min}$ at room temperature. Extracts were analyzed by SDS-PAGE followed by silver staining and PageBlue ${ }^{\mathrm{TM}}$ staining.

\subsubsection{Reducing agent extract}

See Fig. 1B. For developing a method for combined extraction of both gliadins and glutenins, we tested whether the total gluten protein content could be extracted directly using $50 \%(v / v)$ aqueous iso-propanol containing $1 \%(\mathrm{w} / \mathrm{v})$ DTT as reducing agent. Fifty milligrams of flour was extracted with $0.5 \mathrm{ml} 50 \%(\mathrm{v} / \mathrm{v})$ aqueous iso-propanol, $50 \mathrm{mM}$ Tris- $\mathrm{HCl}(\mathrm{pH} 7.5)$ containing $1 \%(\mathrm{w} / \mathrm{v})$ DTT for $30 \mathrm{~min}$ at $60^{\circ} \mathrm{C}$ followed by centrifugation at $10,000 \times \mathrm{g}$ for $10 \mathrm{~min}$ at room temperature. The supernatant is referred to as the 'DTT extract' and was analyzed by SDS-PAGE followed by silver staining and PageBlue ${ }^{\mathrm{TM}}$ staining.

\subsection{3. $60 \%$ ethanol extract}

See Fig. 1C. To obtain $60 \%$ aqueous ethanol extracts, $50 \mathrm{mg}$ of flour was extracted with $1.5 \mathrm{ml} 60 \%(\mathrm{v} / \mathrm{v}$ ) aqueous ethanol for $1 \mathrm{~h}$ with continuous mixing at room temperature followed by centrifugation at $10,000 \times g$ for $10 \mathrm{~min}$ at room temperature. The supernatant is referred to as the ' $60 \% \mathrm{EtOH}$ extract' and was analyzed by SDS-PAGE followed by silver staining, immunoblotting and RIDASCREEN $^{\circledR}$ Gliadin competitive ELISA (see below). The residue was extracted once with $60 \%$ ethanol.

\subsubsection{Two-step gluten extract}

See Fig. 1D. Gluten protein extraction from wheat flour in our two-step protocol, as proposed and evaluated here, was carried out in 50\% (v/v) aqueous iso-propanol (1:10, w/v) and continuous mixing (MS1 Minishaker, IKA Works, Inc.) at $1000 \mathrm{rpm}$ for $30 \mathrm{~min}$ at room temperature, followed by centrifugation at $10,000 \times g$ for $10 \mathrm{~min}$ at room temperature. The residue was extracted twice with $50 \%(\mathrm{v} / \mathrm{v}$ ) aqueous iso-propanol, $50 \mathrm{mM}$ Tris- $\mathrm{HCl}$ ( $\mathrm{pH} 7.5)$ containing $1 \%(\mathrm{w} / \mathrm{v})$ DTT $(1: 10)$ for $30 \mathrm{~min}$ at $60^{\circ} \mathrm{C}$ with mixing every $5-10 \mathrm{~min}$, followed by centrifugation at $10,000 \times \mathrm{g}$ for $10 \mathrm{~min}$ at room temperature. Upon addition of each sequential extraction solution the residue was resuspended by shaking in a Fastprep FP220A Instrument for $10 \mathrm{~s}$ at speed $6.5 \mathrm{~m} / \mathrm{s}$ followed by sonication for $10 \mathrm{~min}$ in an ultrasonic bath (Branson 3510, Branson Ultrasonics Corporation). The supernatants are referred to as the '1st gluten extract', '2nd gluten extract' and ' 3 rd gluten extract'. The extracts were analyzed separately, than combined and referred to as the 'two-step gluten extract'. Extracts were analyzed by SDS-PAGE, immunoblotting and RIDASCREEN ${ }^{\circledR}$ Gliadin competitive ELISA. The remaining proteins (mostly albumins and globulins) in the residue were extracted with $25 \mathrm{mM}$ Tris- $\mathrm{HCl}$ ( $\mathrm{pH} \mathrm{8.0)}$ containing $2 \%$ SDS $(1: 20, \mathrm{w} / \mathrm{v})$ and finally with $25 \mathrm{mM}$ Tris- $\mathrm{HCl}(\mathrm{pH} 8.0)$ containing $2 \%(\mathrm{w} / \mathrm{v})$ SDS and $1 \%(\mathrm{w} / \mathrm{v})$ DTT $(1: 20, \mathrm{w} / \mathrm{v})$ [35]. Both for $30 \mathrm{~min}$ at $60^{\circ} \mathrm{C}$ with mixing every $5-10 \mathrm{~min}$, followed by centrifugation at $14,000 \mathrm{rpm}$ for $10 \mathrm{~min}$ at room temperature. The supernatants, referred to as the 1 st and 2 nd residual extracts, were analyzed for protein content and analyzed by SDS-PAGE followed by silver staining and by immunoblotting to test for any remaining T-cell stimulatory gluten proteins.

\subsection{SDS-PAGE and immunoblotting}

The protein content of all extracts was quantified using BioRad Protein Assay, based on the Bradford dye-binding procedure, according to manufacturer's instruction.

Proteins were separated on SDS-PAGE gels (10\%) as described [36] using a Hoefer SE 260 mighty small II system (GE Healthcare) followed by silver staining [37] or staining with PageBlue ${ }^{\mathrm{TM}}$ (Fermentas).

For immunoblotting, proteins were blotted onto nitrocellulose (0.2 $\mu \mathrm{m}$, Bio-Rad Laboratories), omitting methanol from the blotting buffer, using a Mini Trans-Blot Cell (Bio-Rad Laboratories) at $100 \mathrm{~V}$ for $1 \mathrm{~h}$. Blots were incubated and visualized as described [38] using monoclonal antibodies (mAbs) specific for T-cell stimulatory 


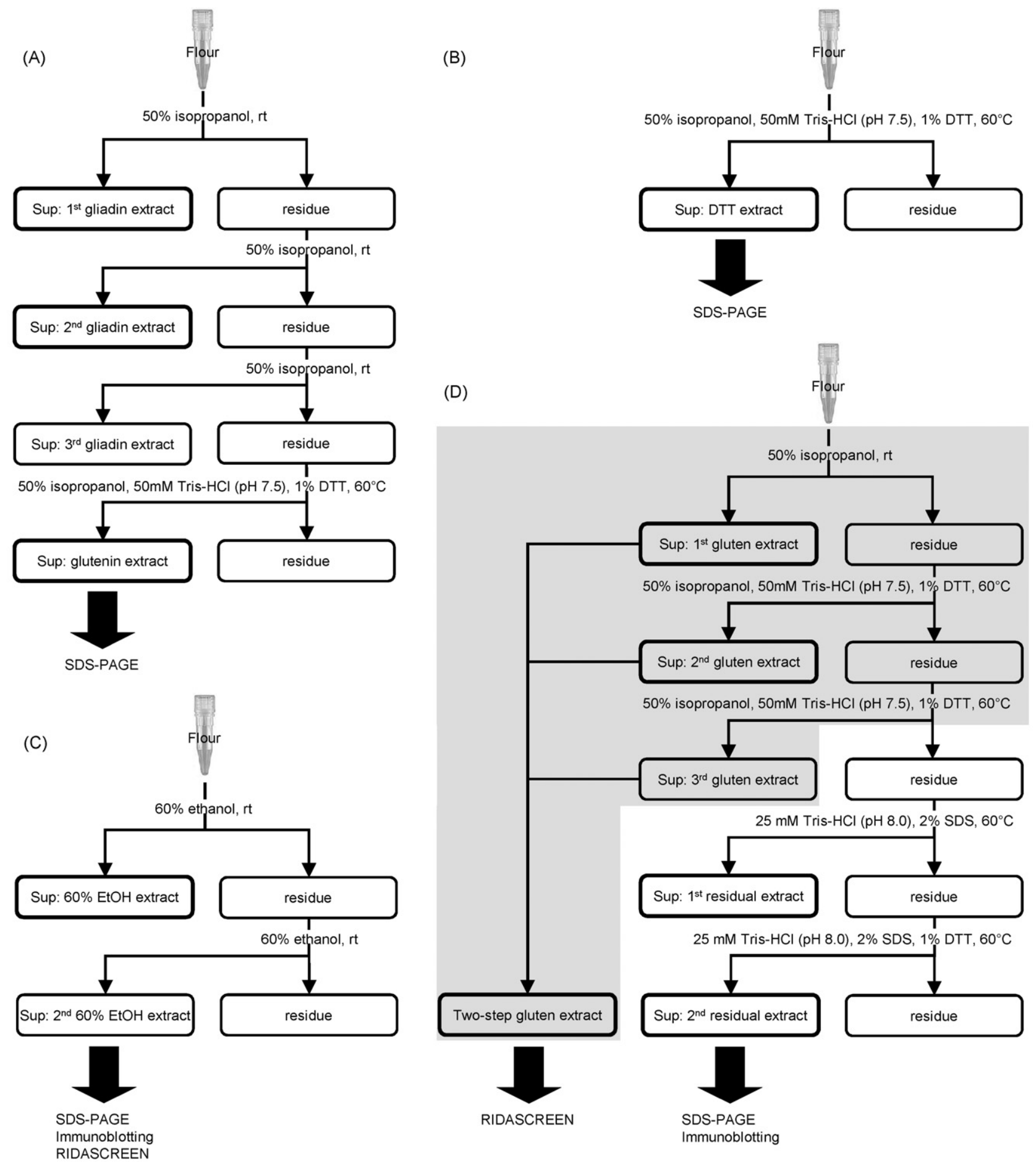

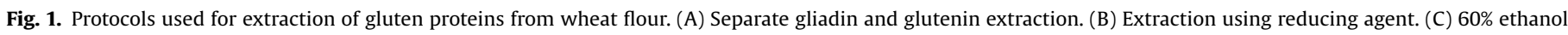
extraction. (D) Two-step gluten extraction (gray box). Extracts from boxes with bold lines were analyzed.

epitope Glia- $\alpha 9$ [25,32], LMW glutenin (LMW-2) [32,33] and HMW glutenin $[25,32]$ obtained from Dr. L. Dekking and Prof. F. Koning, Leiden University Medical Centre, The Netherlands.

\subsection{RIDASCREEN ${ }^{\circledR}$ Gliadin competitive ELISA}

For detection of T-cell stimulatory epitopes by the peroxidase R5 conjugated antibody (R5-HRP), we used the RIDASCREEN ${ }^{\circledR}$ Gliadin competitive ELISA instead of the RIDASCREEN ${ }^{\circledR}$ Gliadin, which is a sandwich ELISA and needs at least two epitopes for detection. The RIDASCREEN ${ }^{\circledR}$ Gliadin competitive assay (R-Biopharm AG) was used according to manufacturer's instruction. The 60\% ethanol extracts were compared to the two-step gluten extracts of the four hexaploid wheat varieties. Extracts were diluted to fit the standard curve. The same extracts were analyzed by immunoblotting using the R5-HRP antibody, visualized by chemiluminescence.

\subsection{Database searching}

The protein database of the National Center for Biotechnology Information (http://www.ncbi.nlm.nih.gov/) was searched on November 6,2008 , for the presence of the sequences recognized by 
the mAbs R5 (QQPFP, QQQFP, LQPFP and QLPFP), Glia- $\alpha 9$ (QPFPQPQ) and LMW glutenin (QSPF). From the NCBI protein database, five different groups of gluten protein sequences from Triticum aestivum were extracted: $\alpha / \beta$-gliadins, $\gamma$-gliadins, $\omega$-gliadins/D-type LMWGS, LMW-GS, and HMW-GS. Within the $\gamma$-gliadins, four sequences (AAA34286, P04729, P04730, and AAA34285) were more similar to LMW-GS and were transferred to the LMW-GS. The $\omega$-gliadins/Dtype LMW-GS group consisted three $\omega$-gliadin sequences and three D-type LMW-GS sequences.

\section{Results}

\subsection{Separate 'gliadin' and 'glutenin' extracts}

To develop a quantitative gluten protein extraction protocol for wheat, several described extraction protocols were analyzed for their level of co-extraction of glutenins and gliadins (Fig. 1). Pre-extraction of gliadins from flour with 50\% iso-propanol is in general performed prior to glutenin extraction to prevent cross-contamination of gliadins in the glutenin fraction. However, pre-extraction could also remove glutenins from the sample. To analyze the level of co-extraction of glutenins while preextracting gliadins with 50\% iso-propanol, three 'gliadin' extracts were obtained by sequential extraction with $50 \%$ iso-propanol
(Fig. 1A). Finally, a 'glutenin' extract was obtained by extraction of the residue with $50 \%$ iso-propanol, $50 \mathrm{mM}$ Tris- $\mathrm{HCl}(\mathrm{pH} \mathrm{7.5)}$ containing 1\% DTT (Fig. 1A). The average protein content in the '1st gliadin extract' of the four hexaploid wheat varieties was 1.21 $( \pm 0.01) \mathrm{mg} / \mathrm{ml}$. In the '2nd gliadin extract' the average protein content was $0.71( \pm 0.03) \mathrm{mg} / \mathrm{ml}$, while in the '3rd gliadin extract' it was only $0.02( \pm 0.01) \mathrm{mg} / \mathrm{ml}$, demonstrating that all 'gliadins' were extracted from the flour before the final glutenin extraction. The average protein content in the 'glutenin extracts' was 0.61 $( \pm 0.01) \mathrm{mg} / \mathrm{ml}$. The '1st and 2 nd gliadin extracts' and the 'glutenin extracts' were compared to analyze the level of co-extraction of gliadins in glutenin extracts and vice versa. The '3rd gliadin extract' was not analyzed further because of the low protein content. These extracts were compared with 'DTT extracts'. Proteins were separated on SDS-PAGE gels followed by silver staining (Fig. 2A) or staining with PageBlue ${ }^{\mathrm{TM}}$ (Fig. 2B). PageBlue ${ }^{\mathrm{TM}}$ is an end-stain procedure that stains HMW-GS more efficiently than silver nitrate does [39]. Results in Fig. 2 show that large amounts of overlapping proteins are present in the 'gliadin' and 'glutenin' extracts. In all four varieties the amount of HMW-GS is even higher in the '2nd gliadin extract' than in the '1st gliadin extract', showing that HMWGS are easily extracted with 50\% iso-propanol without reducing agent. Proteins from the $\omega$-gliadins/D-type LMW-GS region are more abundantly present in the ' 1 st and 2 nd gliadin extracts' com-

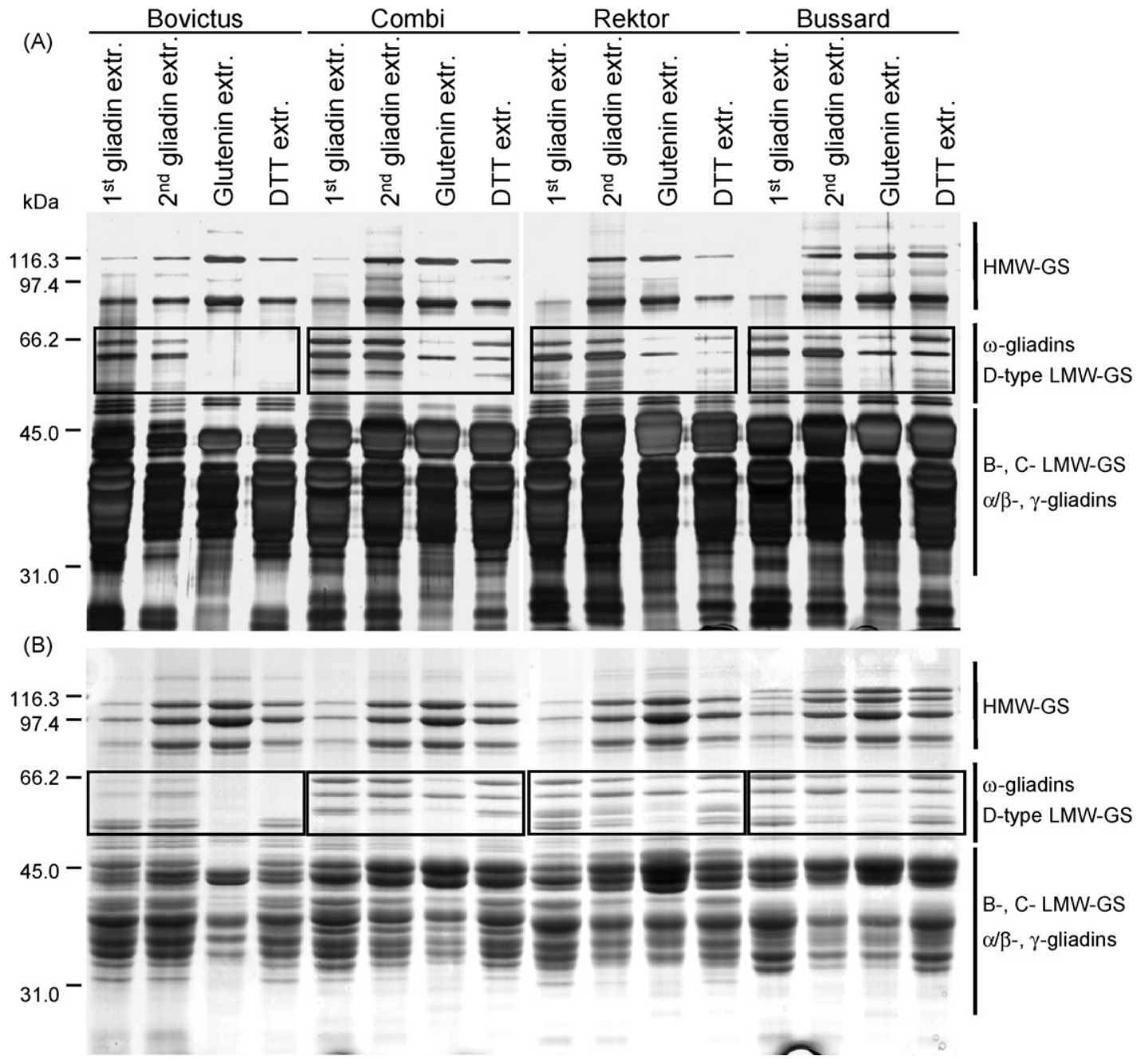

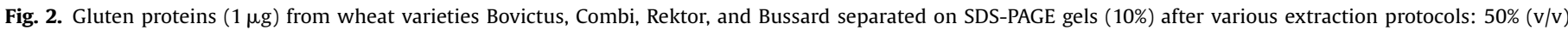

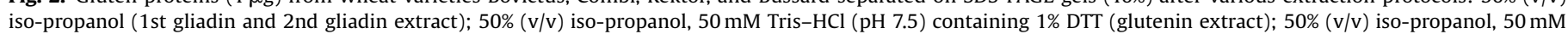
Tris-HCl (pH 7.5) containing 1\% DTT (DTT extract). (A) Silver staining. (B) PageBlue ${ }^{\mathrm{TM}}$ staining. 
pared to the 'glutenin extracts' and 'DTT extracts' (Fig. 2, boxed proteins), especially for variety Bovictus.

\subsection{Reducing agent extract}

To analyze whether the total gluten protein content could be extracted by one single extraction using a reducing agent, wheat flour was extracted with $50 \%$ iso-propanol containing $1 \%$ DTT. The average protein content in these extracts was $1.01 \mathrm{mg} / \mathrm{ml}( \pm 0.00)$. Proteins were separated on SDS-PAGE gels followed by silver staining (Fig. 2A) or staining with PageBlue ${ }^{\mathrm{TM}}$ (Fig. 2B). Results in Fig. 2 (boxed proteins) show that proteins from the $\omega$-gliadins/Dtype LMW-GS region are more abundantly present in the '1st and 2nd gliadin extracts' compared to the 'glutenin extracts' and 'DTT extracts', especially for variety Bovictus. These results show that the gluten proteins cannot be extracted quantitatively by one single

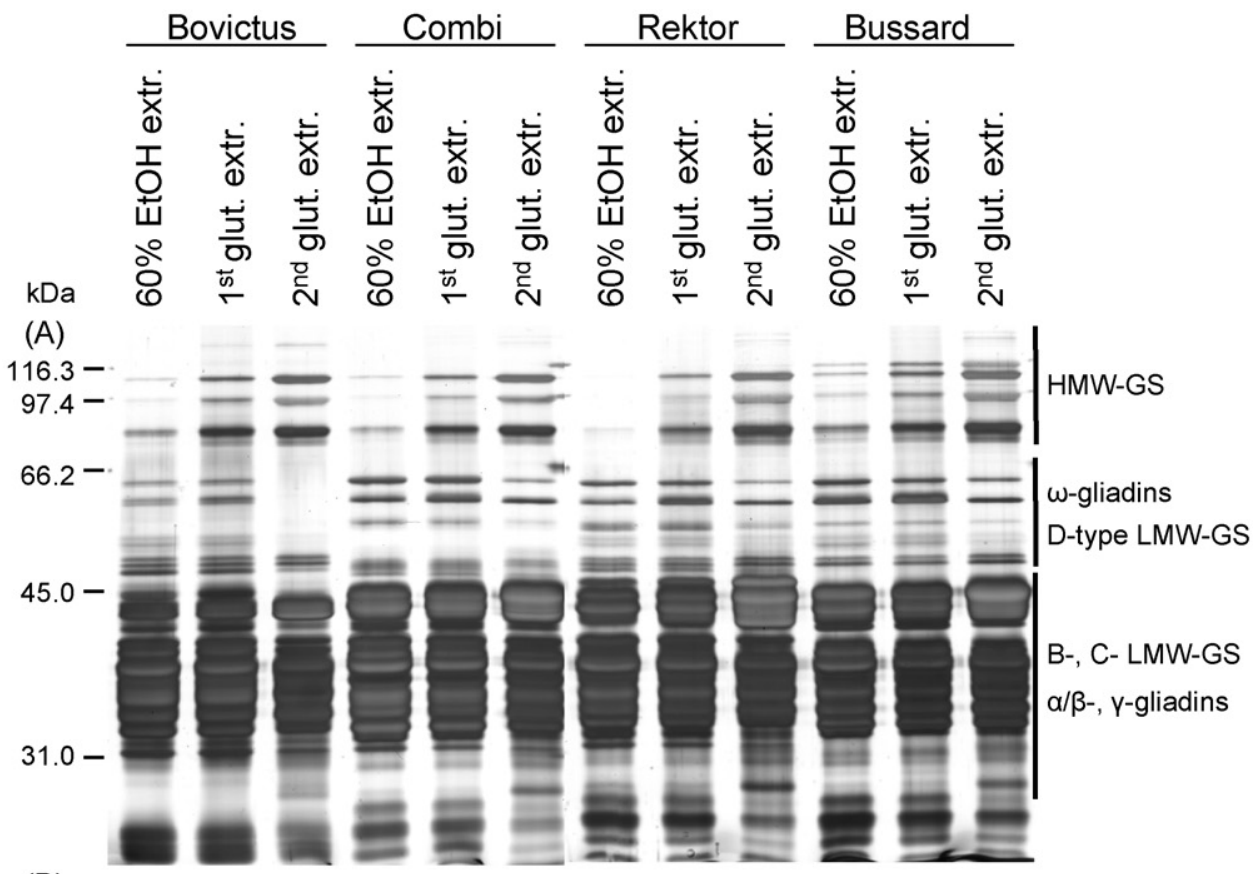

$116.3-$

$97.4-$

$66.2-$

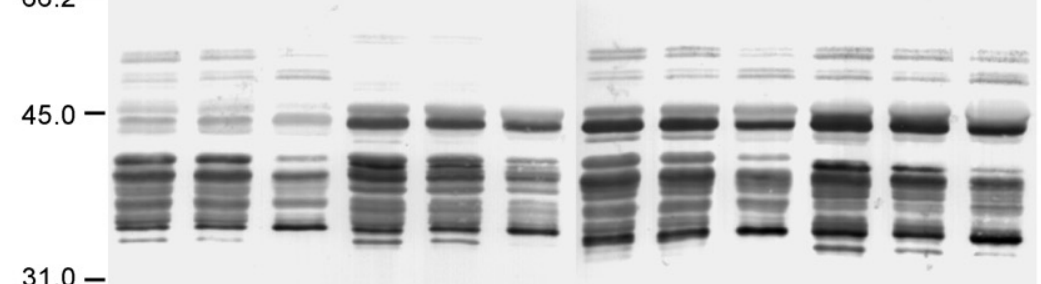

$31.0-$

(C)

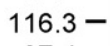

$97.4-$

$66.2-$

$45.0-$

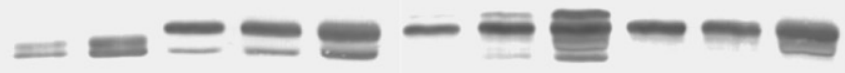

$31.0-$

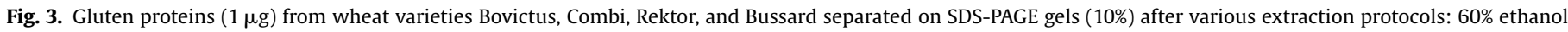

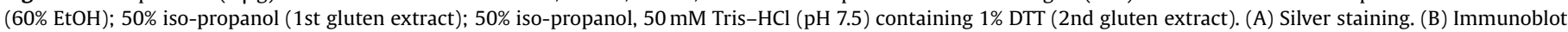
using $\mathrm{mAb}$ against Glia- $\alpha 9$. (C) Immunoblot using mAb against LMW glutenin (LMW-2). 


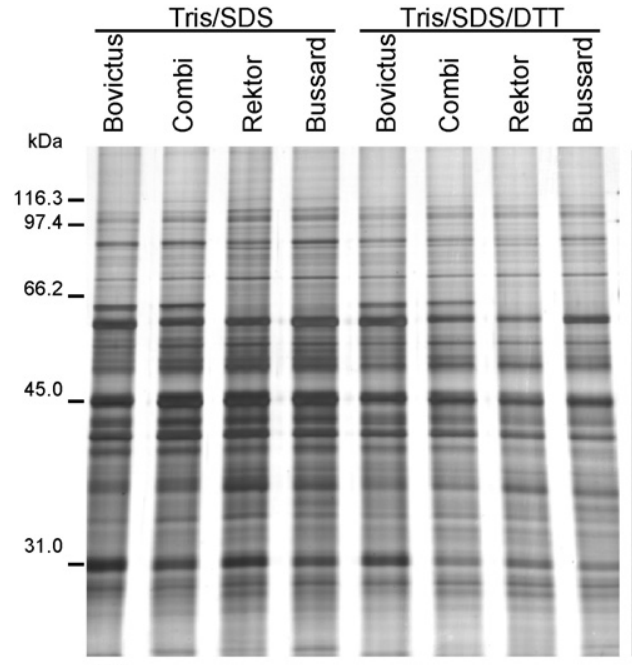

(A)

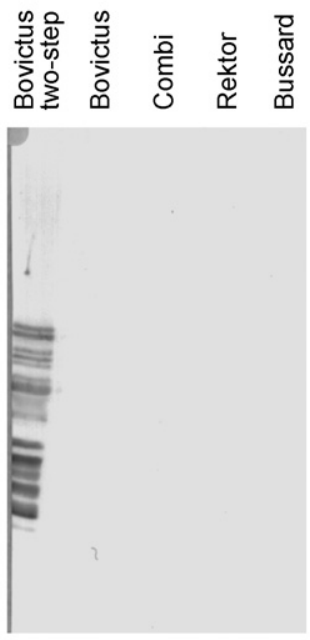

(B)

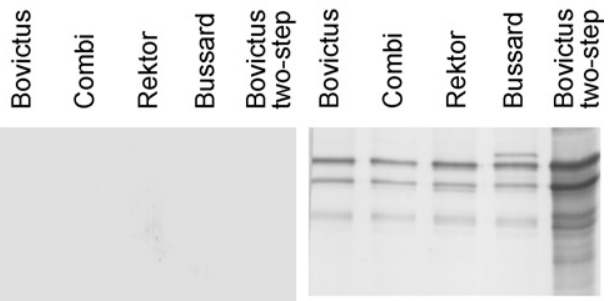

(D)

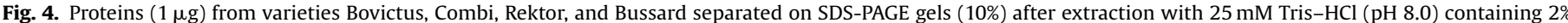

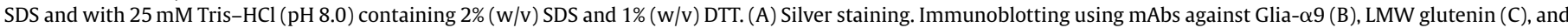
HMW glutenin (D), compared to the two-step gluten extract from variety Bovictus.

extraction including $1 \%$ DTT. In addition, these results show that to extract gluten proteins quantitatively from wheat flour, the protocol should start with a 50\% iso-propanol extraction without DTT.

\section{3. $60 \%$ ethanol extract}

To test gluten protein extracts in immunoassays, in general, extraction is performed with $60 \%$ ethanol. Extractions were performed on the flour of the four wheat varieties and the average protein content of the $1 \mathrm{st} 60 \%$ ethanol extracts was $0.33 \mathrm{mg} / \mathrm{ml}$ $( \pm 0.03)$. The residue obtained after the 1 st $60 \%$ aqueous ethanol extraction was extracted once more, but the average protein content of the supernatants was only $0.03 \mathrm{mg} / \mathrm{ml}( \pm 0.00)$. Proteins from the 1 st $60 \%$ ethanol extract were separated on SDS-PAGE gels followed by silver staining (Fig. 3).

\subsection{Two-step gluten protein extract}

To determine whether we could completely extract gluten proteins in a two-step protocol, we performed sequential extractions starting first with 50\% iso-propanol followed by extracting the residue twice with 50\% iso-propanol, $50 \mathrm{mM}$ Tris- $\mathrm{HCl}$ ( $\mathrm{pH} 7.5$ ) containing 1\% DTT (Fig. 1D). To optimize the extraction of the gluten proteins from the flour, a ratio flour to buffer of $1: 10(\mathrm{w} / \mathrm{v})$ was used instead of $1: 5(\mathrm{w} / \mathrm{v})$. The average protein content in the three gluten extractions obtained was $1.52( \pm 0.14) \mathrm{mg} / \mathrm{ml}, 0.33( \pm 0.03) \mathrm{mg} / \mathrm{ml}$, and $0.06( \pm 0.01) \mathrm{mg} / \mathrm{ml}$, respectively. The 3rd extraction resulted in very low protein concentrations indicating that three extractions were sufficient to highly complete extract the gluten proteins. Proteins from the 1st and 2nd gluten extracts were separated on SDS-PAGE gels followed by silver staining (Fig. 3). Extraction of the residue with $25 \mathrm{mM}$ Tris- $\mathrm{HCl}(\mathrm{pH} 8.0)$ containing $2 \%$ SDS (1st residual extract) and with $25 \mathrm{mM}$ Tris- $\mathrm{HCl}$ ( $\mathrm{pH} \mathrm{8.0)}$ containing $2 \%$ SDS and 1\% DTT (2nd residual extract) resulted in an average protein concentration of $0.84( \pm 0.09) \mathrm{mg} / \mathrm{ml}$ and $0.08( \pm 0.02) \mathrm{mg} / \mathrm{ml}$, respectively. Proteins from the residual extracts were separated on SDS-PAGE gels followed by silver staining and immunoblotting. Silver stained gels showed that some HMW-GS and probably some $\omega$-gliadins/D-type LMW-GS were still extracted with $25 \mathrm{mM}$ Tris- $\mathrm{HCl}$ (pH 8.0) containing $2 \%$ SDS (Fig. 4A).

\subsection{Immunoblotting}

The extracts obtained by 60\% ethanol (Fig. 1C, 1st 60\% EtOH extract) and by our two-step protocol (Fig. 1D, 1st and 2nd gluten extracts) were subsequently compared. They were analyzed for Tcell stimulatory gliadins and glutenins by immunoblotting using mAbs specific for T-cell stimulatory epitopes Glia- $\alpha 9$ (Fig. 3B), LMW glutenin (Fig. 3C), and for the R5-HRP antibody (results not shown). Immunoblotting was followed by analysis using the RIDASCREEN $^{\circledR}$ Gliadin competitive ELISA (Table 1) to determine the degree of completeness of both extraction protocols in order to relate the protocols to $\mathrm{CD}$. Results showed that by extraction with $50 \%$ iso-propanol in our two-step protocol, higher concentrations of HMW-GS were obtained compared to extraction with $60 \%$ ethanol (Fig. 3A). This result suggests that $60 \%$ ethanol is less efficient to extract HMW-GS, maybe because 50\% iso-propanol is more a-polar. Immunoblotting using mAb Glia- $\alpha 9$ showed that $60 \%$ ethanol extracts and 50\% iso-propanol extracts gave comparable results (Fig. 3B). Extracts obtained by extraction with $50 \%$ iso-propanol, $50 \mathrm{mM}$ Tris- $\mathrm{HCl}$ ( $\mathrm{pH} 7.5$ ) containing 1\% DTT showed less proteins reacting with $\mathrm{mAb}$ Glia- $\alpha 9$, because most gliadins already had been extracted with $50 \%$ aqueous iso-propanol. Using $\mathrm{mAb}$ against LMW-glutenin showed increased levels of proteins in both the $50 \%$ iso-propanol extracts and the extracts obtained by $50 \%$ iso-propanol, $50 \mathrm{mM}$ Tris- $\mathrm{HCl}$ ( $\mathrm{pH} 7.5$ ) containing $1 \%$ DTT, in comparison to the $60 \%$ ethanol extracts (Fig. 3C). Proteins from

Table 1

RIDASCREEN ${ }^{\circledR}$ Gliadin competitive ELISA.

\begin{tabular}{lr}
\hline & ppm $\left(\times 10^{6}\right)$ \\
\hline $60 \%$ ethanol extract & \\
Bovictus & $21.30( \pm 3.5)$ \\
Combi & $13.94( \pm 0.7)$ \\
Rektor & $8.32( \pm 0.7)$ \\
Bussard & $13.88( \pm 0.2)$ \\
Two-step gluten extract & \\
Bovictus & $21.17( \pm 0.2)$ \\
Combi & $11.32( \pm 0.9)$ \\
Rektor & $8.26( \pm 0.2)$ \\
Bussard & $10.03( \pm 0.4)$ \\
\hline
\end{tabular}

Comparison of $60 \%$ ethanol extracts and two-step gluten extracts of hexaploid wheat varieties. Errors are standard errors of the mean of duplicate measurements. 
Table 2

Database search result for epitope sequences present in gluten proteins from Triticum aestivum.

\begin{tabular}{|c|c|c|c|c|c|c|}
\hline $\mathrm{mAb}$ & $\alpha / \beta$-gliadins & $\gamma$-gliadins & $\omega$-gliadins/D-type LMW-GS & LMW-GS & HMW-GS & Total \\
\hline \multicolumn{7}{|l|}{ R5 } \\
\hline QQPFP & $63(65)$ & $91(354)$ & $3^{a}(47)$ & $60(79)$ & 0 & $218(545)$ \\
\hline QQQFP & $42(59)$ & $78(134)$ & $5^{\mathrm{b}}(56)$ & $17(43)$ & 0 & $142(292)$ \\
\hline LQPFP & $69(77)$ & 0 & 0 & 0 & 0 & $69(77)$ \\
\hline QLPFP & 0 & $36(36)$ & $1^{\mathrm{c}}(1)$ & 0 & 0 & $37(37)$ \\
\hline \multicolumn{7}{|l|}{ LMW-2 } \\
\hline QSPF & 0 & 0 & 0 & $155(155)$ & 0 & $155(155)$ \\
\hline \multicolumn{7}{|l|}{ Glia- $\alpha 9$} \\
\hline QPFPQPQ & $68(68)$ & $67(152)$ & $3^{d}(10)$ & 0 & 0 & $138(230)$ \\
\hline Total number of protein sequences in database & 84 & 94 & 6 & 236 & 68 & 420 \\
\hline
\end{tabular}

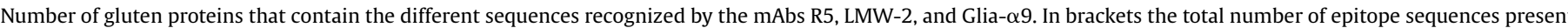
in the proteins.

a $2 \omega$-gliadins, 1 D-type LMW-GS.

b $3 \omega$-gliadins, 2 D-type LMW-GS.

c $1 \omega$-gliadin.

d $2 \omega$-gliadins, 1 D-type LMW-GS.

the residual extracts were separated on SDS-PAGE gels followed by immunoblotting using mAbs specific for T-cell stimulatory epitope Glia- $\alpha 9$, LMW glutenin, and HMW glutenin. Immunoblots did not show any reaction of proteins with the mAbs Glia- $\alpha 9$ (Fig. 4B) and LMW glutenin (Fig. 4C). In contrast, some HMW-GS were indeed still present that reacted with the mAb against HMW glutenin (Fig. 4D). Apparently, these HMW-GS are part of a complex that could not be extracted by $50 \%$ iso-propanol or by $50 \%$ iso-propanol, 50 mM Tris- $\mathrm{HCl}$ ( $\mathrm{pH} 7.5$ ) containing 1\% DTT. Peptides from HMW-GS were identified to bind to HLA-DQ8 receptors $[40,41]$, whereas purified HMW-GS were shown to stimulate T-cells of patients that were HLA-DQ2 and HLA-DQ8 [42,43]. As the largest part of the HMWGS was extracted in our two-step protocol, it was concluded that the main gluten protein content was extracted with our two-step protocol.

\subsection{RIDASCREEN ${ }^{\circledR}$ Gliadin competitive ELISA}

The sequentially obtained extracts in our two-step protocol were combined to obtain two-step gluten extracts (Fig. 1D). The twostep gluten extracts and the 60\% ethanol extracts were analyzed and compared using the RIDASCREEN ${ }^{\circledR}$ Gliadin competitive ELISA. The results (Table 1 ) showed no major differences between the two different extracts of each variety, only differences among the varieties were observed. The values measured for total gluten content (in ppm) were high, which is expected if pure wheat samples are analyzed. In accordance with the RIDASCREEN ${ }^{\circledR}$ Gliadin competitive ELISA, the immunoblot resulted in similar patterns for the $60 \%$ ethanol extracts and two-step gluten extracts from each variety (results not shown).

\subsection{Database searching}

A protein database search (http://www.ncbi.nlm.nih.gov/) of gluten protein sequences from T. aestivum was searched for the presence of the sequences recognized by the mAbs R5 (QQPFP, QQQFP, LQPFP and QLPFP), Glia- $\alpha 9$ (QPFPQPQ) and LMW-2 (QSPF). This search resulted in three $\omega$-gliadin/D-type LMW-GS sequences out of six that contained the QQPFP sequence (Table 2). Within two $\omega$-gliadin sequences, the QQPFP sequence appeared 13 and 14 times. Within $\gamma$-gliadin sequences, QQPFP appeared with a maximum of eight times per sequence. Within $\alpha$-gliadin sequences, QQPFP appeared mostly once per sequence. Within LMW-GS sequences, 60 out of 236 contained the QQPFP sequence, while as many as 155 LMW-GS sequences contained the LMW-2 mAb sequence (QSPF). This explains the higher signals in immunoblotting in both the 1 st gluten extracts (50\% iso-propanol) and 2nd gluten extracts (50\% iso-propanol, $50 \mathrm{mM}$ Tris- $\mathrm{HCl}$ (pH 7.5) containing $1 \%$ DTT) compared to $60 \%$ ethanol extracts, when using the LMW glutenin $\mathrm{mAb}$ (Fig. 3C). No HMW-GS sequences were found that contained QQPFP, QQQFP, LQPFP, or QLPFP sequences.

\section{Discussion}

Here we describe a two-step extraction protocol that is especially suitable for highly complete extraction of gluten proteins and is compatible with assays for detection and quantification of T-cell stimulatory epitopes with specific monoclonal antibodies. The protocol is based on the subsequent combination of extraction of gliadins and glutenins. Based on comparison with other existing gluten extraction protocols, we obtained more complete and higher overall gluten protein content and specifically higher concentrations of glutenins. The strength of our two-step extraction protocol is that it starts directly with the extraction of gluten proteins without pre-extraction to remove albumins and globulins. Starting the protocol with 50\% iso-propanol enables the extraction of $\omega$-gliadins/D-type LMW-GS that are not extracted in 50\% iso-propanol containing DTT.

Bread and pasta wheat breeding has resulted in thousands of different wheat varieties. Recent research using crude extracts from a limited selection of wheat varieties showed large variation of epitope-specific T-cell responses and antibody binding between these varieties [33]. It is relevant to analyze the variation in immune response among these existing varieties in detail in order to find varieties having low (or non) T-cell stimulatory epitopes for direct use or for further breeding. Multiple T-cell stimulatory gluten epitopes are especially found in $\alpha$-gliadins, but also in $\gamma$-gliadins and glutenins [33,34]. To analyze the immune response of many wheat varieties and species (including diploids, tetraploids, and hexaploids), our two-step extraction protocol proved to be highly useful.

Obtained gluten protein extracts were tested with the RIDASCREEN ${ }^{\circledR}$ Gliadin competitive ELISA. Competitive ELISA is preferred over the sandwich ELISA because the latter requires at least two epitope sequences if the same $\mathrm{mAb}$ is used for binding and detection. In that case, the sandwich ELISA may result in underestimation of T-cell stimulatory epitopes. On the other hand, competitive ELISA will only produce an accurate estimation of T-cell stimulatory epitopes if specific $m A b s$ are used. Less specific antibodies may result in false negative or false positive results. The high 
signals generated by the antibody used in the RIDASCREEN ${ }^{\circledR}$ Gliadin competitive ELISA correlates with the known presence of multiple and diverse epitope sequences within the proteins. The low sensitivity of the R5 mAb for LMW-GS explains why the RIDASCREEN ${ }^{\circledR}$ Gliadin competitive ELISA did not detect obvious differences in LMW-GS presence across extraction protocols. Although no remarkable differences between the $60 \%$ ethanol extracts and the two-step gluten extracts were observed using the RIDASCREEN ${ }^{\circledR}$ Gliadin competitive ELISA, clear differences between the extracts were shown by immunoblotting using specific mAbs against other Tcell stimulatory epitopes. The $\mathrm{R} 5 \mathrm{mAb}$ recognizes different small peptide sequences (QQPFP, QQQFP, LQPFP, and QLPFP) which are present mainly in gliadin proteins. The sequence LQPFP, which is strongly recognized by the $\mathrm{R} 5 \mathrm{mAb}$, is present in the T-cell stimulatory proteolysis-resistant 33-mer [44]. However, this sequence is only present in $\alpha$-gliadins. The RIDASCREEN ${ }^{\circledR}$ Gliadin competitive ELISA is used to detect 'gluten' in general in food products. Because of the presence of many recognition sites for the $\mathrm{R} 5 \mathrm{mAb}$, this may lead to overestimation of T-cell stimulatory epitopes. In case of the recognition of the R5 mAb of LMW-GS epitopes, there is an underestimation of T-cell stimulatory epitopes. These facts make the R5 mAb not well suitable for quantification. Immunoblotting using specific $\mathrm{mAbs}$ against $\mathrm{CD}$ immune responsive epitopes as applied in our protocol is therefore more useful to characterize the T-cell stimulatory capacity of wheat varieties, as the epitopes are not distributed randomly across gliadins and glutenins [45-47]. The antibodies used in the present study, which are specifically generated against specific T-cell stimulatory epitopes, in combination with our two-step extraction protocol, thus enable to quantify T-cell stimulatory epitopes in a certain food product.

\section{Conclusion}

The extraction protocol proposed here enables to highly complete extraction of the gluten proteins from wheat flour. For quantification of the 'epitope load' for CD-patients, the combination with a set of $\mathrm{CD}$-related $\mathrm{T}$-cell stimulatory epitope specific antibodies is essential.

\section{Acknowledgements}

This research was supported by the Celiac Disease Consortium, an Innovative Cluster approved by The Netherlands Genomics Initiative and partially funded by the Dutch Government (BSIK03009), and by the Dutch Ministry of Agriculture, Nature, and Food Safety (project KB-05-001-019-PRI). Many thanks to Prof. Frits Koning and Dr. Liesbeth Dekking (Leiden University Medical Centre, The Netherlands) for providing us with the monoclonal antibodies.

\section{References}

[1] M.F. Kagnoff, in: S.G.L. Auricchio, L. Maiuri, R. Troncone (Eds.), Coeliac Disease, JCG Editions, Naples, Italy, 2000, p. 5.

[2] P. Margaritte-Jeannin, M.C. Babron, M. Bourgey, A.S. Louka, F. Clot, S. Percopo, I. Coto, J.P. Hugot, H. Ascher, L.M. Sollid, L. Greco, F. Clerget-Darpoux, Tissue Antigens 63 (2004) 562.

[3] A.S. Louka, L.M. Sollid, Tissue Antigens 61 (2003) 105.

[4] G. Mazzarella, M. Maglio, F. Paparo, G. Nardone, R. Stefanile, L. Greco, Y. van de Wal, Y. Kooy, F. Koning, S. Auricchio, R. Troncone, Gut 52 (2003) 57.
[5] P.J. Ciclitira, Gastroenterology 120 (2001) 1526

[6] L.M. Sollid, Nat. Rev. Immunol. 2 (2002) 647.

[7] T.B. Osborne, The Protein of the Wheat Kernel, Carnegie Institution of Washington, 1907 (Publication 84).

[8] J.H. Woychik, J.A. Boundy, R.J. Dimler, Arch. Biochem. Biophys. 94 (1961) 477.

[9] E.A. Jackson, L.M. Holt, P.I. Payne, Theor. Appl. Genet. 66 (1983) 29.

[10] H.D. Sapirstein, W. Bushuk, Cereal Chem. 62 (1985) 372.

[11] B.A. Marchylo, J.E. Kruger, D.W. Hatcher, J. Cereal Sci. 9 (1989) 113.

[12] N.K. Singh, K.W. Shepherd, G.B. Cornish, J. Cereal Sci. 14 (1991) 203.

[13] W. Weiss, C. Vogelmeier, A. Görg, Electrophoresis 14 (1993) 805.

[14] V. Melas, M.H. Morel, J.C. Autran, P. Feillet, Cereal Chem. 71 (1994) 234.

[15] I.M. Verbruggen, W.S. Veraverbeke, A. Vandamme, J.A. Delcour, J. Cereal Sci. 28 (1998) 25.

[16] J. Suchy, O.M. Lukow, B.X. Fu, J. Sci. Food Agric. 83 (2003) 1083.

[17] F.M. Dupont, W.J. Hurkman, W.H. Vensel, C.K. Tanaka, K.M. Kothari, O.K. Chung, S.B. Altenbach, Eur. J. Agron. 25 (2006) 96.

[18] W.J. Hurkman, C.K. Tanaka, J. Cereal Sci. 40 (2004) 295.

[19] W.J. Hurkman, C.K. Tanaka, J. Chromatogr. B 849 (2007) 344.

[20] A.R. Freedman, G. Galfrè, E. Gal, H.J. Ellis, P.J. Ciclitira, J. Immunol. Methods 98 (1987) 123.

[21] F.G. Chirdo, M.C. Añon, C.A. Fossati, Food Agric. Immunol. 7 (1995) 333.

[22] H.J. Ellis, S. Rosen-Bronson, N. O’Reilly, P.J. Ciclitira, Gut 43 (1998) 190.

[23] L. Sorell, J.A. López, I. Valdés, P. Alfonso, E. Camafeita, B. Acevedo, F. Chirdo, J. Gavilondo, E. Méndez, FEBS Lett. 439 (1998) 46.

[24] I. Valdés, E. García, M. Llorente, E. Méndez, Eur. J. Gastroen. Hepat. 15 (2003) 465.

[25] E.H.A. Spaenij-Dekking, E.M.C. Kooy-Winkelaar, W.F. Nieuwenhuizen, J.W. Drijfhout, F. Koning, Gut 53 (2004) 1267.

[26] E. Méndez, C. Vela, U. Immer, F.W. Janssen, Eur. J. Gastroen. Hepat. 17 (2005) 1053.

[27] B. Morón, M. Bethune, I. Comino, H. Manyani, M. Ferragud, M. López, A. Cebolla, C. Khosla, C. Sousa, PLoS ONE 28 (2008) e2294.

[28] V. Doña, C. Fossati, F. Chirdo, Eur. Food Res. Technol. 226 (2008) 591.

[29] E. Garcia, M. Llorente, A. Hernando, R. Kieffer, H. Wieser, E. Mendez, Eur. J Gastroen. Hepat. 17 (2005) 529.

[30] Codex Alimentarius Commission, Codex standard for foods for special dietary use for persons intolerant to gluten, http://www.codexalimentarius.net/ download/standards/291/cxs_118e.pdf.

[31] F. Kahlenberg, D. Sanchez, I. Lachmann, L. Tuckova, H. Tlaskalova, E. Méndez, T. Mothes, Eur. Food Res. Technol. 222 (2006) 78.

[32] C. Mitea, Y. Kooy-Winkelaar, P. van Veelen, A. de Ru, J.W. Drijfhout, F. Koning, L. Dekking, Am. J. Clin. Nutr. 88 (2008) 1057.

[33] L. Spaenij-Dekking, Y. Kooy-Winkelaar, P. van Veelen, J.W. Drijfhout, H. Jonker L. van Soest, M.J.M. Smulders, D. Bosch, L.J.W.J. Gilissen, F. Koning, Gastroenterology 129 (2005) 797.

[34] W. Vader, Y. Kooy, P. van Veelen, A. de Ru, D. Harris, W. Benckhuijsen, S. Peña, L. Mearin, J.W. Drijfhout, F. Koning, Gastroenterology 122 (2002) 1729.

[35] F.M. DuPont, V. Samoil, R. Chan, J. Agric. Food Chem. 56 (2008) 7431

[36] U.K. Laemmli, Nature 227 (1970) 680.

[37] T. Rabilloud, G. Carpentier, P. Tarroux, Electrophoresis 9 (1988) 288

[38] J.H.G. Cordewener, G. Hause, E. Görgen, R. Busink, B. Hause, H.J.M. Dons, A.A.M Van Lammeren, M.M. Van Lookeren Campagne, P. Pechan, Planta 196 (1995 747.

[39] H.C. van den Broeck, A.H.P. America, M.J.M. Smulders, L.J.W.J. Gilissen, I.M. van der Meer, Proteomics 8 (2008) 1880.

[40] Y. van de Wal, Y.M.C. Kooy, P.A. van Veelen, W. Vader, S.A. August, J.W. Drijfhout, S.A. Peña, F. Koning, Eur. J. Immunol. 29 (1999) 3133.

[41] F. Koning, L. Gilissen, C. Wijmenga, Springer Semin. Immunopathol. 27 (2005) 217.

[42] Ø. Molberg, N.E.S. Flæte, T. Jensen, K.E.A. Lundin, H. Arentz-Hansen, O.D. Anderson, A.K. Uhlen, L.M. Sollid, Gastroenterology 125 (2003) 337.

[43] D.H. Dewar, M. Amato, H.J. Ellis, E.L. Pollock, N. Gonzalez-Cinca, H. Wieser, P.J Ciclitira, Eur. J. Gastroenterol. Hepatol. 18 (2006) 483.

[44] L. Shan, Ø. Molberg, I. Parrot, F. Hausch, F. Filiz, G.M. Gray, L.M. Sollid, C. Khosla, Science 297 (2002) 2275.

[45] Ø. Molberg, A.K. Uhlen, T. Jensen, N.E.S. Flæte, B. Fleckenstein, H. Arentz-Hansen, M. Raki, K.E.A. Lundin, L.M. Sollid, Gastroenterology 128 (2005) 393.

[46] T.W.J.M. van Herpen, S.V. Goryunova, J. van der Schoot, M. Mitreva, E.M.J. Salentijn, O. Vorst, M.F. Schenk, P. van Veelen, F. Koning, L.J.M. van Soest, B. Vosman, D. Bosch, R.J. Hamer, L.J.W.J. Gilissen, M.J.M. Smulders, BMC Genomics 7 (2006)

[47] E.M.J. Salentijn, S.V. Goryunova, N. Bas, I.M. van der Meer, H.C. van den Broeck, T. Bastien, L.J.W.J. Gilissen, M.J.M. Smulders, BMC Genomics 10 (2009) 48. 